\title{
Improved Upland Rice: Adaptability, Agronomic and Farmer Acceptability Assessment under Semi-Arid Conditions of South Western Uganda
}

\author{
Peace Kankwatsa $^{1 *}$, Robert Muzira ${ }^{1}$, Hellen Mutenyo ${ }^{1}$, Jimmy Lamo ${ }^{2}$ \\ ${ }^{1}$ Mbarara Zonal Agricultural Research and Development Institute (MBAZARDI), Mbarara, Uganda \\ ${ }^{2}$ National Crop Resources Research Institute (NaCCRI), Kampala, Uganda \\ Email: ^kankwatsap@gmail.com, nrmuzira@gmail.com, mutenyoh@gmail.com, lamojim@gmail.com
}

How to cite this paper: Kankwatsa, P., Muzira, R., Mutenyo, H. and Lamo, J. (2019) Improved Upland Rice: Adaptability, Agronomic and Farmer Acceptability Assessment under Semi-Arid Conditions of South Western Uganda. Open Access Library Journal, 6: e5660.

https://doi.org/10.4236/oalib.1105660

Received: August 2, 2019

Accepted: December 21, 2019

Published: December 24, 2019

Copyright ( $) 2019$ by author(s) and Open Access Library Inc.

This work is licensed under the Creative Commons Attribution International License (CC BY 4.0).

http://creativecommons.org/licenses/by/4.0/

\begin{abstract}
Enhancing the ability of plants to tolerate abiotic and biotic stresses is the current strategy for increasing agricultural productivity worldwide. Improved upland rice varieties characterized by early maturity, high disease resistance, high drought tolerance, high yielding potential, high grain quality and marketability are required by farmers to increase upland rice production to meet the increasing food and income demands. Improved and local upland rice varieties were evaluated across two seasons with and without fertilizer application. Insufficient soil water availability, low soil fertility and the blast disease were the major stresses that affected upland rice in the Rubirizi and Mitooma experimental sites in the South Western Agro Ecological Zone of Uganda. Integration of improved rice variety and soil fertility amendment with fertilizer plus proper crop management cultural practices resulted in high agronomic performance. Varieties NamChe 4, NamChe 5 and E22 showed superior performance over the other varieties in the field, and had significantly high probability $(\mathrm{P} \leq 0.15)$ of being accepted by farmers. The early maturing NERICA 10, late maturing NERICA 6, SUPERICA 1 and Local Var., had high probabilities of being rejected because of low yielding, late maturity, drought intolerance, small panicle size, poor grain filling and high susceptibility to rice blast caused by Magnaporthe grisea. Therefore, improved varieties have great potential of increasing rice production in SWAEZ-Uganda, if farmers adopt the multi-technology integration approach.
\end{abstract}

\section{Subject Areas}

Agricultural Science 


\section{Keywords}

Upland Rice, Adaptability, Agronomic Performance, Variety Preference and Acceptability

\section{Introduction}

The growing importance of rice in Uganda propelled the government to join the Coalition for African Rice Development (CARD) formed in 2008 [1], with the goal of doubling rice production to increase food-security and income of smallholders in Sub-Saharan Africa in 10 years [2]. Initially, rice was prioritized as a non-traditional crop for household poverty alleviation in Uganda, with commercial companies and small holder farmers mainly in Pallisa, Butaleja, Iganga, Lira, Gulu and Bundibugyo districts as the major producers. Expansion of rice production to the current rice growing districts including Kyankwanzi, Hoima, Tororo, Soroti, Kumi, Masindi, Apac, Bugiri, Kamwenge, Wakiso, Mukono, Kasese, Buhweiju, Rukungyiri, Mitooma, Kanungu and Rubirizi, has shown significant increases in the annual rice production overtime [3].

The decline in wetland grown paddy rice yields since the 1980s is attributed to continuous growing of low yielding varieties, recycling of degenerated seed, low soil fertility, pests/diseases and insufficient water availability [4] [5] [6]. Most of the local paddy rice varieties grown in wetlands are late maturing (120 - 140 days), and susceptible to diseases, indicating a need to adopt and adapt the improved varieties to the prevailing farming conditions. Moreover, decline in soil fertility has also caused an increase in the cost of production [7], and overuse of fertilizers that may eventually have a negative impact on the entire wetland ecosystem.

Therefore, enhancing the ability of rice plants to tolerate biotic and abiotic stresses is the current strategy for increasing agricultural productivity worldwide. Moreover, due to climatic change, continued disturbance of wetlands is not only disastrous to the eco-system, but also increases the contribution of agriculture to greenhouse gas emission into the atmosphere resulting in global warming associated effects [8]. Studies have shown adoption of high yielding rice varieties that utilize most of the photosynthates or substrates in grain filling rather than vegetative growth and rooting reduces the amount of substrates availed to the methanogenic bacteria in the rhizosphere zone. Although rice is known to contribute greenhouse gas (GHG) emissions including $\mathrm{CH}_{4}, \mathrm{NO}_{2}$ and $\mathrm{CO}_{2}$ [8] [9], strategies to ensure optimal yields, and also reduce GHG emission by this crop need to be sought.

Apart from the Eastern Uganda regions where the initial introduction of rice was successful mainly because of the availability of sufficient water for growing lowland rice varieties, the introduction of upland rice during the early 2000s spread rice production to farmers (mostly small holders) in new areas [11]. The 
rainfed upland NERICA varieties in Uganda introduced in 2002, have shown great potential of increasing rice production [10], especially in the semi-arid Western and North-Western regions where it is most grown. During 2002-2009, the area under rice (especially the New Rice for Africa: NERICA) production increased from 1500 ha to over 50,000 ha while yields increased to a range of 1.1 $5.8 \mathrm{t} / \mathrm{ha}$ across diverse agro-ecological zones. The upland varieties are currently competing with the commonly grown paddy rice varieties because they are highly resistant to diseases, mature earlier (90 - 120 days), high yielding (potentially 4 - $6 \mathrm{t} / \mathrm{ha}$ unmilled) and grows under moderate water availability [11]. According to Oonyu (2011), upland rice is a promising better alternative to paddy rice for sustainable production and household income generation [4], especially under the prevailing drought-prone climatic condition. A study by Haneishi (2014) showed that besides the high input requirement, growing high yielding NERICA upland rice varieties that were found to increase crop income by $40 \%$ $60 \%$ [11], may be more profitable especially to smallholder farmers than some other upland crops. The high demand and market price in urban areas makes rice a commodity farmers continue to invest in for income generation [2] [12].

In the SWAEZ, rainfed upland rice is commonly grown in Rubirizi and Mitooma districts, which are located at the edge of the Western Great Rift Valley, and are characterised by bi-annual rainfall pattern with short rains occurring in March-May and long rains during September-December. In this region, rice is grown purposely for income generation [13], but due to limited resources, farmers wholly rely on rainfall to water their crops, and therefore the timely sowing calendar is strictly followed.

Elsewhere, studies have shown significant upland rice responses to fertilizer-legume cover crop combinations with more than $100 \%$ grain yield increase resulting in higher profit-gain especially when appropriate fertilizer quantities are used [14]. Neither fertilizer nor farmer yard manure (FYM) is utilized in upland rice production, because of the prohibitive high costs involved in accessing and applying the recommended qualities and quantities of fertilizers in the SWAEZ. Moreover, lack of information/knowledge about fertilizer use and profitability prevent farmers from benefiting from it [15].

The 2000-2070 predicted impact of climate change in Africa, showed yield decline for both irrigated and rain fed rice in all environments of East Africa due to limited water and nutrient availability, and temperature rise [16]. Typically, when plants shorten their growth period in event of abrupt water scarcity, yield deficits occur. Although Uganda is still advantaged because its higher soil fertility and relatively high annual rainfall (800 - $1200 \mathrm{~mm}$ per year) compared to other African countries, the climate change threat may severely affect rice production if well adaptable varieties are not developed [17]. Therefore, the current focus on developing climate change resilient rice through breeding early maturing, high drought tolerant and high yielding varieties, is the appropriate strategy. Improved upland rice varieties have been developed by the National Crop Re- 
sources Research Institute (NaCRRI) in Uganda in collaboration with other institutions [12]. Although farmers grow some of these improve upland rice varieties (NERICA and NamChe) plus other mixed local varieties, the agronomic performance of the improved varieties under farmers' conditions in SWAEZ is not well known. Losses caused by the major biotic and abiotic stresses like diseases (rice blast caused by Magnaporthe grisea) and soil fertility related stresses, respectively, have not been well studied. Therefore, this research was carried to determine the adaptability and agronomic performance of improved rice varieties in terms of resilience to abiotic (drought and low soil fertility) and biotic (pest/disease) stresses under farmers' conditions in Rubirizi and Mitooma districts. Farmer- or consumer-preferred varieties were selected based on their specific characteristics.

\section{Materials and Methods}

Improved upland rice varieties including E22, NamChe 3, NamChe 4, NamChe 5, NERICA 6 and NERICA 10 were kindly provided by Dr. Jimmy Lamo a breeder at the Cereals Program-NaCRRI-NARO (National Crop Resources Research Institute, National Agricultural Research Organisation) Uganda. The local mixed and SUPERICA 1 varieties were provided by farmers and a private company, respectively. On-farm experiments were carried in two major upland rice growing districts of the SWAEZ namely Rubirizi and Mitoma. Twenty farmers hosted the experiment during the short and long rain seasons of 2017.

1) Field characterization and soil fertility assessment: Each field was characterized based on the previous cropping patterns, soil management practices and soil characteristics. Initial soil physical and chemical properties were determined using soil samples collected from five points per experimental field using an auger at the depth of $0-15 \mathrm{~cm}$. The laboratory analyses of the composite soil samples were carried out at the National Agricultural Research Laboratories (NARL), Kawanda Kampala-Uganda.

2) Field experiments and data collection: Eight rice varieties were evaluated through a Randomised Complete Block Design (RCBD) experiment, at inter:intra row hill spacings of $30 \mathrm{~cm}: 15 \mathrm{~cm}$ per plot for two seasons. Each plot had 11 lines sown with six seeds per hill ( 21 holes/line). Inter-plot spacing was $0.5 \mathrm{~m}$ while spacing between main treatments was $1 \mathrm{~m}$. The main experimental treatment was soil amendment with fertilizers [DAP applied at rate of $50 \mathrm{~kg} / \mathrm{ha}$ at planting, followed by subsequent applications of urea at $120 \mathrm{~kg} / \mathrm{ha}$ and $\mathrm{Mu}-$ riate of potash $(\mathrm{MOP})$ at $60 \mathrm{Kg} / \mathrm{ha}$ ] and without fertilizer application. The subplot was variety (E22, NamChe 3, NamChe 4, NamChe 5, NERICA 6, NERICA 10, SUPERICA 1 and Local Var.). Sowing was done at a seed rate of $80 \mathrm{~kg} / \mathrm{ha}$ in February and July/August just before the onset of the first and second rain seasons, respectively. Weeding was done twice per season, and no supplementary irrigation was applied. The on-farm trials were established and managed by farmers with technical support from the researchers and the ex- 
tension workers.

Data were collected on the following parameters using criteria modified for on-farm trials: time to germination (days after planting to time when each variety was $50 \%$ germination), number of plants that germinated (percent germination $=($ numbers of plants that germinated per plot/total seeds planted in plot $) \times$ $100\}$, plant vigour $(1=$ low, $5=$ high), leaf area diseased (using the standard scale of $0 \%-100 \%$ ), maturity period (days after planting - DAP to mature grain), tolerance to drought $(1=$ low, $3=$ High), number of tillers with mature panicles and yield (kg). Rice blast was the major fungi diseases assessed in this study, and the leaf area infection data were collected on 20 randomly selected hills per plot. Data collection was initiated at about 26 - 34 days after planting when the first symptoms appeared on the susceptible local variety. The subsequent weekly percent $(0 \%-100 \%)$ leaf area infections were scored five times (ending at $58-69$ days after planting).

The percentage data on leaf area infected were used to calculate area under disease progress curve (AUDPC) using the following formula described by Shaner and Finney (1977) [29]: AUDPC $\left.=\left[\left(X_{1}+X_{2}\right) \star N_{1}\right) / 2\right]+\left[\left(X_{2}+X_{3}\right) *\right.$ $\left.N_{2}\right) / 2$ ], where $X_{1}, X_{2}$ and $X_{3}$ represented percent leaf area infected on the $1^{\text {st }}, 2^{\text {nd }}$, $3^{\text {rd }} \ldots \mathrm{n}^{\text {th }}$ assessment. $N_{1}$ and $N_{2}$ represented intervals (days) between every two data collection dates [30]. Analysis of Variance (ANOVA) was used to compare means via the GenStat 17th Ed. (VNSI) programme. The Least Significant Difference test (LSD) at $\mathrm{P} \leq 0.05$ was used to assess pairwise significance of means when the overall ANOVA F-test was significant. To measure the strength of association between different variables, correlation analysis was applied.

\section{3) Upland variety evaluation and preference ranking}

Seven rice varieties were further evaluated using the matrix scores and preference ranking by farmers to identify the most preferred varieties based on agronomic characteristics at stages 8-9 (dough stage - mature grain). The farmer participatory evaluation criteria were developed to suit the selected panel that comprised of farmers and agricultural extension workers. Thus, a modified version of the standard matrix score method ranging from 1 (least performing) to 5 (best performing) was used to assess: tillering ability, yielding potential, panicle size, grain filling, disease and pest tolerance/resistance; a scale of 1-2 scores was used to assess maturity period and a scale of 1-3 was used to assess drought tolerance. The logistics preference ranking analysis was used to assess the overall order of acceptability of the various rice varieties.

\section{Results}

Although rice in Uganda has been commonly grown in the low-lying wetlands, the high agronomic performance of upland varieties at an altitude range of 1000 - 1200 masl (Figure 1) in this study, revealed that mid-elevation cropping land in Uganda has high potential for upland rice production. Agronomic performance of rice in the Rubirizi district sites located at 1005 - 1311 masl was higher 
compared to the Mitooma district sites located at 1101 - 1174 masl. Rice is known to grow best on well drained fertile loamy soil comprising clay and/or organic matter, but the current study revealed that upland rice also grows well on sandy soil with low clay and loam compositions (Figure 2) in the SWAEZ. Apart from the two experimental sites that had $42 \%$ - 43\% sandy soils, the sand compositions in the soil samples from all other sites ranged from $52 \%$ to $80 \%$, an indication of high drainage and low water holding capacity. The soil $\mathrm{pH}$ range was 3.9 - 6.3 with slightly more than half of the sites having $\mathrm{pH}$ range of 5.5 - 6.3. Seventy-five percent of soils had organic matter contents $(1.3 \%-4.8 \%)$ lower than the critical level (5.0\%), an observation already noted in the low loam soil composition.

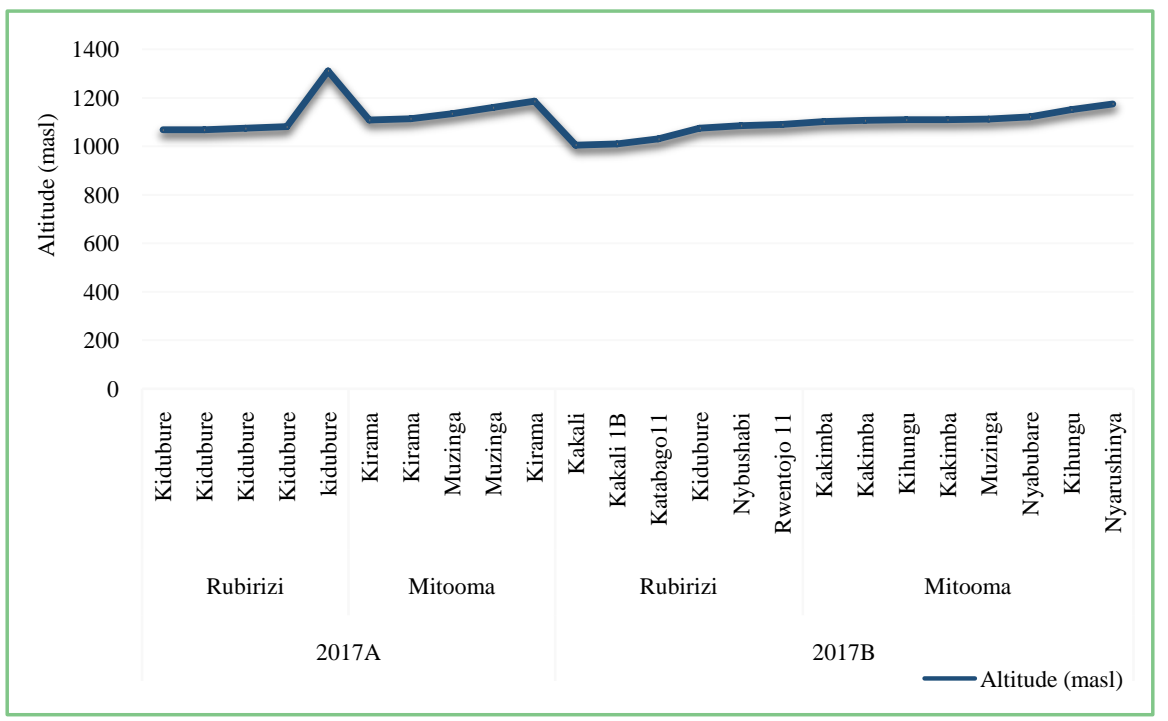

Figure 1. Locations (altitude masl) of upland rice experimental-sites in Rubirizi and Mitooma districts in the South Western Agro-Ecological Zone (SWAEZ) of Uganda.

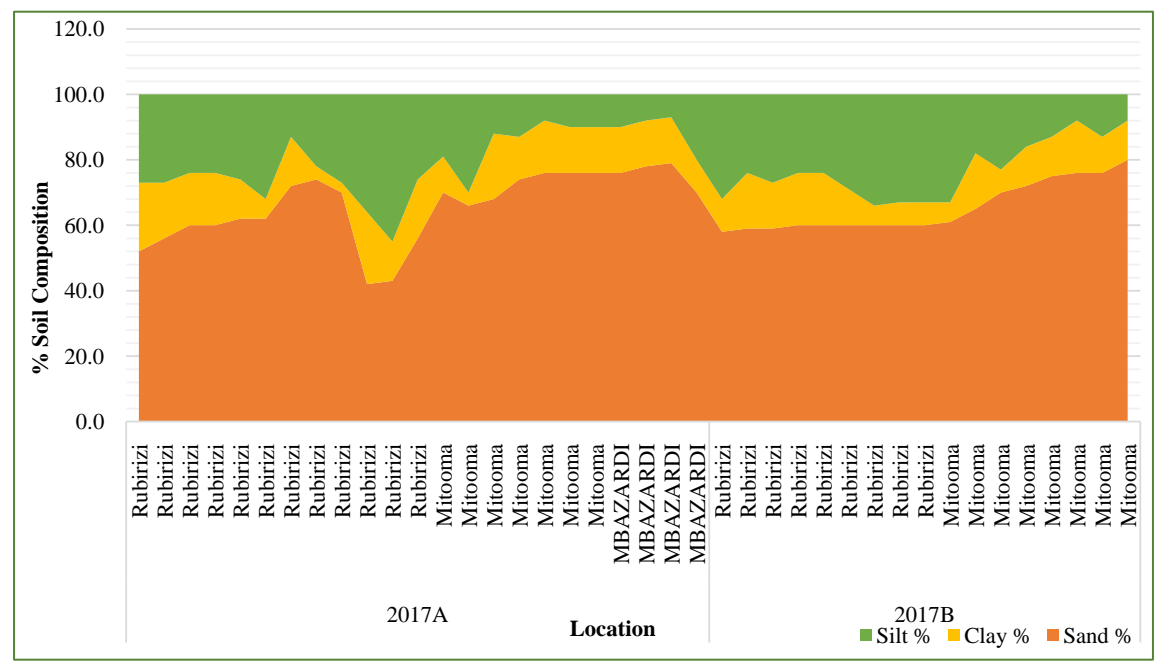

Figure 2. Percent compositions of sand, loam and clay components of soil samples collected from the upland rice experimental-sites in Rubirizi and Mitooma districts during the short and long cropping seasons of 2017. 
Besides the Nitrogen level that was close to the critical level (0.2), phosphorus (P) varied from $2.1 \%$ to $79.0 \%$, with half of the samples having the high $\mathrm{P}$ range of 27.3 - 79.0. Like the Nitrogen component, the levels of Potassium (K) were close to the critical levels in most sites. These results showed that the major nutrients $(\mathrm{N}, \mathrm{P}$ and $\mathrm{K})$ were generally insufficient in most sites, implying that for higher rice production in these sites, the farmers needed to supplement the exiting nutrients with either inorganic or organic fertilizers. The other major elements including Calcium, Sodium and Magnesium were sufficient in most samples (Table 1).

Table 1. Chemical characteristics of soil samples collected from the experimental sites in the South Western Agro Ecological Zone of Uganda.

\begin{tabular}{|c|c|c|c|c|c|c|c|c|c|c|}
\hline Sites & Year & Farmer/Location & $\mathrm{PH}$ & $\mathrm{N} \%$ & O M \% & P Bray & $\mathrm{K}$ & $\mathrm{Ca}$ & $\mathrm{Mg}$ & $\mathrm{Na}$ \\
\hline 1 & $2017 \mathrm{~A}$ & Aruho Vicent & 5.5 & 0.2 & 4.8 & 18.9 & 0.3 & 6.9 & 0.9 & 0.4 \\
\hline 2 & & Kiza Charles Kidubule & 5.1 & - & 13.1 & 5.0 & 0.2 & 4.5 & 0.8 & 0.3 \\
\hline 3 & & Matsiko God Kiyanga & 5.2 & 0.2 & 2.6 & 56.7 & 0.1 & 2.0 & 0.8 & 0.1 \\
\hline 4 & & Kwehangana Benon & 5.9 & 0.3 & 5.3 & 4.6 & 0.7 & 10.1 & 0.9 & 0.8 \\
\hline 5 & & Obadia Mugisha Kiyanga & 4.8 & 0.1 & 2.2 & 27.3 & 0.2 & 2.5 & 0.5 & 0.2 \\
\hline 6 & & Kato Lawrence Katerera & 5.0 & 0.3 & 5.5 & 79.0 & 0.4 & 10.3 & 0.7 & 0.5 \\
\hline 7 & & Kasheija John Katerera & 5.6 & 0.2 & 4.6 & 36.3 & 1.8 & 10.5 & 0.9 & 1.5 \\
\hline 8 & & Kyobugabe Kidubure & 5.6 & 0.2 & 4.2 & 27.9 & 0.4 & 7.5 & 0.9 & 0.3 \\
\hline 9 & & Byabashaija Kiyanga & 3.9 & 0.2 & 3.6 & 48.1 & 0.7 & 3.4 & 0.8 & 0.5 \\
\hline 10 & & Rwakarubanga Ambrose Katerera & 5.9 & 0.3 & 7.3 & 11.6 & 0.9 & 12.3 & 0.9 & 1.0 \\
\hline 11 & & Grace Kemirerenyarubare & 5.8 & 0.3 & 13.7 & 35.5 & 0.6 & 8.0 & 0.9 & 0.7 \\
\hline 12 & & Kyarimpa Veneranda Kidubure & 5.2 & 0.3 & 6.5 & 42.0 & 0.2 & 6.4 & 0.8 & 0.2 \\
\hline 13 & & Wakubaruho Ivan Mitooma & 5.8 & 0.2 & 3.8 & 69.5 & 0.8 & 5.3 & 0.8 & 0.6 \\
\hline 14 & & Justin Aruho Katerera & 5.5 & 0.2 & 4.4 & 3.3 & 0.4 & 5.9 & 0.8 & 0.5 \\
\hline 15 & & Korumogo Kiyanga & 4.6 & 0.1 & 1.7 & 6.0 & 0.2 & 2.5 & 0.6 & 0.2 \\
\hline 16 & & Dan Kanyesigye Kiyanga & 5.3 & 0.1 & 2.2 & 2.3 & 0.6 & 3.1 & 0.8 & 0.6 \\
\hline 17 & & MBAZARDI Main Gate Side Lower & 5.8 & 0.1 & 1.3 & 9.0 & 0.6 & 2.4 & 0.5 & 0.6 \\
\hline 18 & & Main Gate Side Upper & 5.7 & 0.2 & 2.2 & 3.6 & 0.7 & 2.1 & 0.6 & 0.6 \\
\hline 19 & & Kihumuro Side Lower & 5.3 & 0.1 & 2.4 & 4.1 & 0.3 & 1.8 & 0.6 & 0.2 \\
\hline \multirow[t]{2}{*}{20} & & Kihumuro Side Upper & 5.6 & 0.2 & 2.8 & 2.8 & 0.8 & 2.8 & 0.7 & 0.8 \\
\hline & & Average & 5.5 & 0.1 & 2.2 & 4.4 & 0.6 & 2.4 & 0.7 & 0.5 \\
\hline 1 & 2017B & Ampaire Deus & 4.5 & 0.2 & 2.0 & 3.0 & 0.2 & 0.8 & 0.2 & 0.1 \\
\hline 2 & & Ntegyerize Aventina & 5.0 & 0.2 & 1.7 & 7.1 & 0.2 & 1.2 & 0.3 & 0.1 \\
\hline 3 & & Jane Kakuka & 6.0 & 0.3 & 5.3 & 58.8 & 0.4 & 2.8 & 0.3 & 0.2 \\
\hline 4 & & Ahariziira Asaph & 5.9 & 0.2 & 3.6 & 51.1 & 0.6 & 4.9 & 0.4 & 0.1 \\
\hline
\end{tabular}




\section{Continued}

\begin{tabular}{|c|c|c|c|c|c|c|c|c|c|}
\hline 5 & Rwoburunga Musinga & 5.1 & 0.3 & 4.7 & 9.5 & 0.3 & 2.5 & 0.2 & 0.1 \\
\hline 6 & Korumogo Kakimba & 4.7 & 0.2 & 2.2 & 2.4 & 0.3 & 0.8 & 0.2 & 0.1 \\
\hline 7 & Rukundo Jovan & 6.1 & 0.3 & 3.6 & 46.4 & 0.6 & 4.5 & 0.4 & 0.1 \\
\hline 8 & Kato Laurence & 6.3 & 0.3 & 3.5 & 56.1 & 0.8 & 4.4 & 0.3 & 0.2 \\
\hline 9 & Twinomujuni Deo & 5.8 & 0.2 & 3.6 & 37.6 & 0.3 & 5.3 & 0.4 & - \\
\hline 10 & Ahimbisibwe Ferediyana & 4.6 & 0.2 & 2.0 & 2.1 & 0.1 & 0.5 & 0.2 & 0.1 \\
\hline 11 & Tuhumwire Allen & 4.4 & 0.2 & 1.7 & 7.8 & 0.1 & 0.5 & 0.2 & 0.0 \\
\hline 12 & Sanyu Jenipher & 4.8 & 0.2 & 3.1 & 3.5 & 0.1 & 0.5 & 0.2 & 0.0 \\
\hline 13 & Atuhaire Charles & 5.9 & 0.3 & 4.2 & 28.6 & 0.9 & 3.8 & 0.4 & 0.3 \\
\hline 14 & Kwehagana Benon 1 & 5.4 & 0.2 & 4.8 & 37.3 & 0.3 & 6.0 & 0.5 & 0.2 \\
\hline 15 & Kwehagana Benon 2 & 5.6 & 0.2 & 5.0 & 28.5 & 0.2 & 6.3 & 0.5 & 0.2 \\
\hline 16 & Kwehagana Benon 3 & 6.1 & 0.2 & 4.6 & 33.4 & 0.6 & 7.6 & 0.6 & 0.4 \\
\hline 17 & Kwehagana Benon 4 & 6.2 & 0.2 & 5.1 & 47.7 & 0.4 & 7.4 & 0.5 & 0.3 \\
\hline 18 & Kwehagana Benon 5 & 5.6 & 0.2 & 5.0 & 34.6 & 0.2 & 6.1 & 0.5 & 0.2 \\
\hline 19 & Kowonogo Anna & 4.9 & 0.1 & 2.2 & 2.7 & 0.3 & 0.8 & 0.2 & 0.1 \\
\hline \multirow[t]{3}{*}{20} & Alfred Byabasheja & 4.7 & 0.2 & 3.0 & 4.1 & 0.1 & 0.6 & 0.2 & 0.1 \\
\hline & Average & 5.4 & 0.2 & 3.6 & 25.1 & 0.3 & 3.4 & 0.3 & 0.1 \\
\hline & Critical level & 5.5 & 0.2 & 5.0 & 15.0 & 0.3 & 4.0 & 0.5 & \\
\hline
\end{tabular}

Soil mineral percent compositions: N-Nitrogen, OM- Organic Matter, P-Phosphorus, K-Potassium, Ca-Calcium, Mg-Magnesium, Na-Sodium.

The upland rice varieties tested in the current study included six released NERICA and NamChe varieties, a local-mixed check, SUPERICA 1 and two advanced genotypes (E20 and E22). The initial assessment based on average plant vigour, height and tiller formation showed that the fertilizer-variety integration significantly affected the plant growth characteristics. Plots treated with fertilizers showed high growth vigour, plant height and number of mature tillers in all sites during the two seasons (Table 2). Plant vigour was consistently low-moderate (Figure 3(a) and Figure 3(b)) across all varieties with or without fertilizers during the short rain (2017A) and long rain (2017B) seasons (Figure 4). Although plant vigour was non-significantly different in the 2017A season, in 2017B the fertilized plants had significantly higher vigour range of $2.5-3.7$ (Table 2) than the corresponding varieties that were not fertilized (1.7 - 2.8). NamChe 5, NERICA 6, SUPERICA 1 and the local variety had higher average plant vigour in 2017B.

Apart from NERICA 10, that was consistently short across season, variety and soil treatment, the rest of the varieties treated with fertilizers had significantly ( $\mathrm{p}$ $\leq 0.05$ ) higher plant heights than the non-fertilized varieties during 2017A and 2017B. The local variety, NERICA 6 and SUPERICA 1 had the highest average 
plant height with or without fertilizer in both seasons, but the local variety was characterized by weak stems and plant etiolation, which commonly resulted in plant breakage and collapsing.

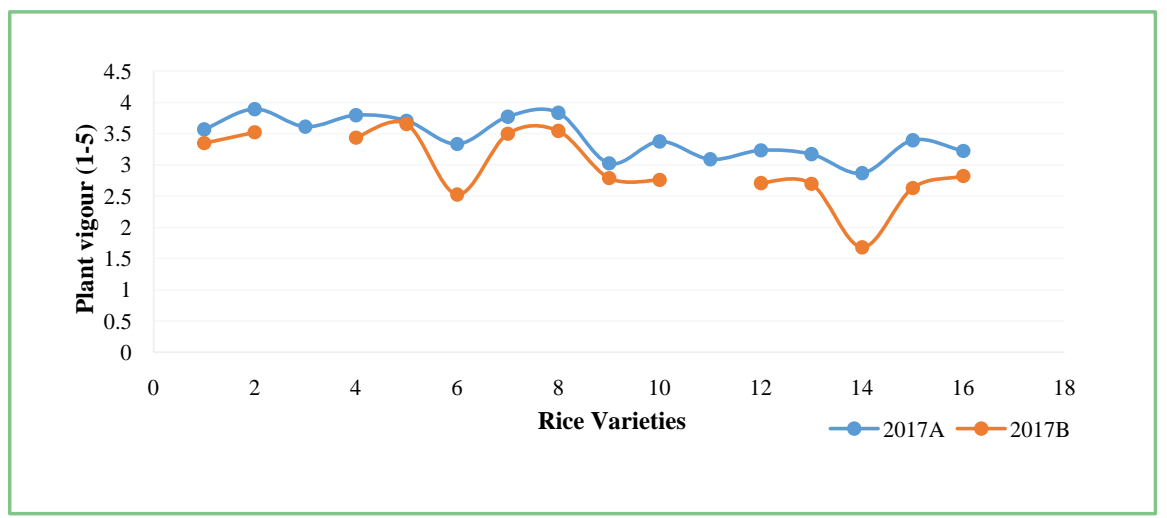

(a)

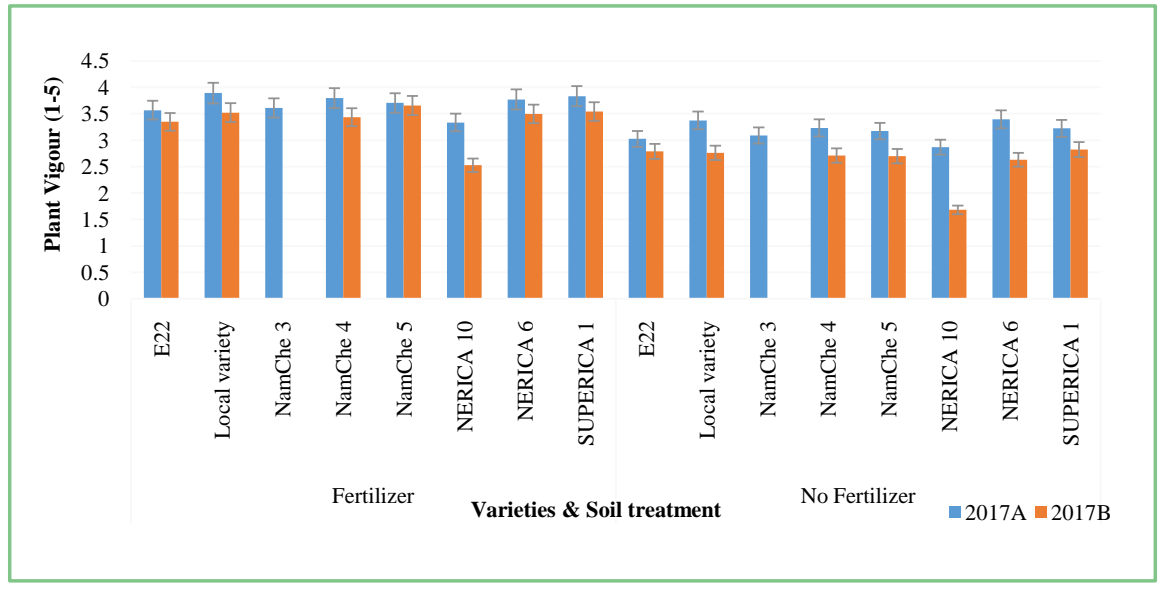

(b)

Figure 3. (a) Plant vigour trends of all varieties during the first season (2017A or short rains) and second (2017B or long rains) seasons; (b) Comparison of plant vigour across varieties and soil treatment with/without fertilizers during 2017A and 2017B.
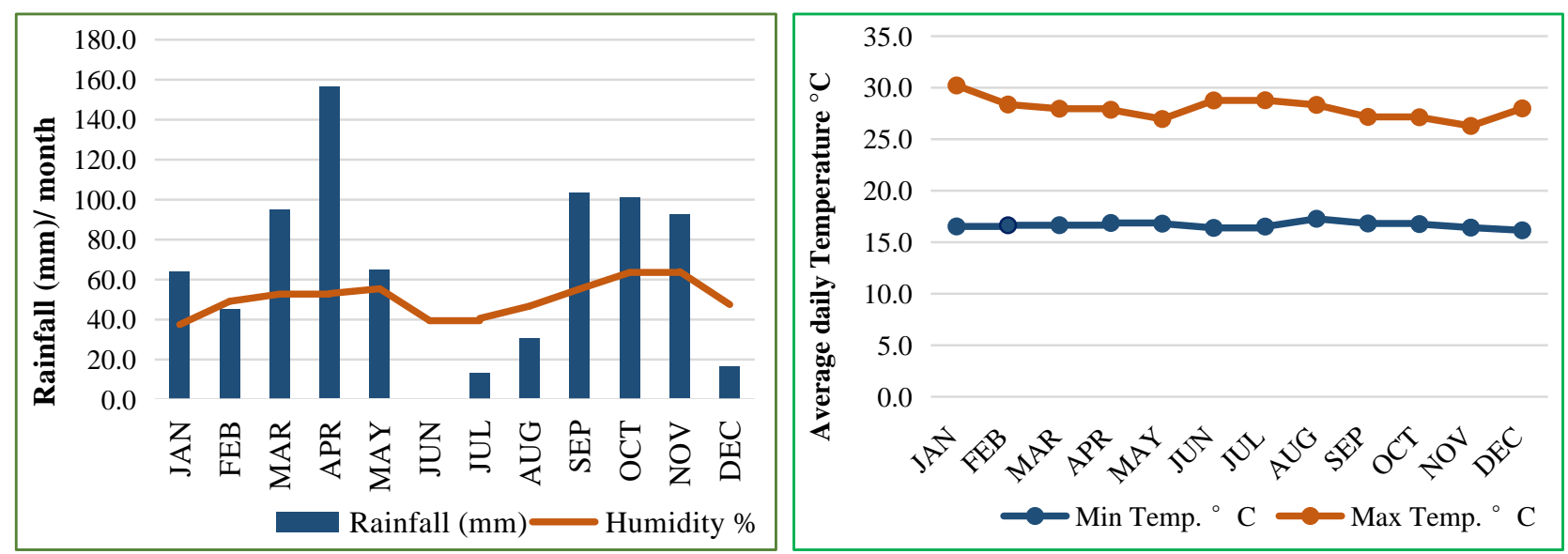

Figure 4. Average monthly rainfall, humidity and temperature during 2017 in the South Western Agro Ecological Zone Uganda. 
Table 2. Plant vigour, height and tiller formation of upland varieties with or without fertilizer use during the first (short rains) and second (long rains) seasons of 2017.

\begin{tabular}{|c|c|c|c|c|c|c|c|}
\hline \multirow[t]{2}{*}{ Soil treatment } & \multirow[t]{2}{*}{ Variety } & \multicolumn{2}{|c|}{ Plant vigour } & \multicolumn{2}{|c|}{ Plant Height $(\mathrm{cm})$} & \multicolumn{2}{|c|}{ Number of tillers } \\
\hline & & 2017A & 2017B & 2017A & 2017B & $2017 \mathrm{~A}$ & 2017B \\
\hline \multirow[t]{8}{*}{ Fertilizer } & E22 & 3.6 & 3.3 & 104.5 & 101.8 & 10.4 & 12.1 \\
\hline & Local variety & 3.9 & 3.5 & 105.9 & 112.6 & 10.9 & 12.4 \\
\hline & NamChe 3 & 3.6 & - & 104.1 & - & 7.7 & - \\
\hline & NamChe 4 & 3.8 & 3.4 & 104.2 & 104.7 & 8.9 & 13.3 \\
\hline & NamChe 5 & 3.7 & 3.7 & 102.2 & 105.4 & 6.9 & 12.9 \\
\hline & NERICA 10 & 3.3 & 2.5 & 56.3 & 81.0 & 2.1 & 7.4 \\
\hline & NERICA 6 & 3.8 & 3.5 & 104.6 & 106.9 & 6.8 & 8.1 \\
\hline & SUPERICA 1 & 3.8 & 3.5 & - & 112.2 & - & 9.2 \\
\hline Average & & 3.7 & 3.4 & 97.4 & 103.5 & 7.7 & 10.8 \\
\hline \multirow[t]{8}{*}{ No Fertilizer } & E22 & 3.0 & 2.8 & 94.7 & 77.3 & 7.9 & 8.0 \\
\hline & Local variety & 3.4 & 2.8 & 89.5 & 81.2 & 8.0 & 6.0 \\
\hline & NamChe 3 & 3.1 & - & 87.3 & - & 7.4 & - \\
\hline & NamChe 4 & 3.2 & 2.7 & 93.1 & 80.2 & 8.7 & 7.4 \\
\hline & NamChe 5 & 3.2 & 2.7 & 90.4 & 81.0 & 6.8 & 7.3 \\
\hline & NERICA 10 & 2.9 & 1.7 & 67.8 & 56.2 & 5.7 & 3.4 \\
\hline & NERICA 6 & 3.4 & 2.6 & 100.9 & 70.3 & 6.5 & 4.4 \\
\hline & SUPERICA 1 & 3.2 & 2.8 & - & 82.5 & - & 5.7 \\
\hline Average & & 3.2 & 2.6 & 89.1 & 75.5 & 7.3 & 6.0 \\
\hline $\operatorname{LSD}_{(\mathrm{P} \leq 0.05)}$ & & NS & 0.3 & 2.5 & 12.1 & 0.9 & 3.5 \\
\hline $\mathrm{CV} \%$ & & 14.1 & 25.9 & 16.2 & 32.1 & 55.1 & 95.2 \\
\hline
\end{tabular}

The average number of mature heading tillers among varieties treated with fertilizers was significantly high during the two seasons with 2017B having slightly more tillers than 2017A (Table 2), and with NamChe 4, NamChe 5, E22 and the local varieties having the highest average number of mature tillers (range was 12.1 - 13.3 per plant). Within the same fertilizer treatment, NERICA 6, NERICA 10 and SUPERICA 1 showed low tillering ability. Besides poor tillering, the slow growth of NERICA 6 negatively affected its yielding across all seasons.

While NERICA 10 seemed to be inherently low tillering, varieties that were not treated with fertilizers also displayed low tillering trend during the two seasons. E22, local Var., NamChe 4 and NamChe 5 had significantly high plant vigour, height and tillering responses to fertilizer application during the two seasons, whereas SUPERICA 1 was partly affected by the blast disease.

Rice blast was the most serious fungi disease in both Rubirizi and Mitooma districts, and high disease severity occurred during the 2017B season, which received higher rainfall (Figure 4). Although, the average percent leaf area diseased (LAD) did not exceed 50\% during the two seasons, the most infected va- 
rieties were the susceptible local Var., and SUPERICA 1 (Table 3). The high disease severity on both varieties resulted in high AUDPC. Improved NERICA and NamChe varieties showed lower blast severity than the other varieties, but plants treated with fertilizers experienced higher rice blast infection than the non-fertilized ones (Figure 5). NERICA 10 was the most blast resistant variety during the two seasons, which may partly be attributed to the sparse tiller population that did not create favourable conditions for the pathogen-inoculum development.

Although there was a negative correlation between disease severity (leaf area infected) and yield, the low value $(\mathrm{r}=-0.042)$ at $\mathrm{p} \leq 0.05$ indicated that the disease had a low effect on yield in the current study. Beside the non-significant 2017A yields, the varieties treated with fertilizers during 2017B had significantly higher yields, with E22, NamChe 4 and NamChe 5 having the highest yields (Figure 5), while SUPERICA 1, NERICA 6 and local variety had lower yields (Table 3) that were partly resultants of the high disease infection. Again NERICA 10 had the lowest yields yet it was the least affected by the disease.

Table 3. Effect of the interaction of soil treatment and variety on leaf blast disease severity and upland rice yield during first (short rains) and second (long rains) seasons of 2017.

\begin{tabular}{|c|c|c|c|c|c|c|c|}
\hline Soil treatment & Variety & $\%$ final leaf area diseased & & ${ }^{* *}$ AUDPC & & Yield $\mathrm{Kg} / \mathrm{h}$ & \\
\hline & & 2017A & 2017B & 2017A & 2017B & $2017 \mathrm{~A}$ & 2017B \\
\hline \multirow[t]{8}{*}{ Fertilizer } & E22 & 6.5 & 7.8 & 102.1 & 237.5 & 7078.0 & $12,515.0$ \\
\hline & Local variety & 25.4 & 20.2 & 319.8 & 779.3 & 4503.0 & $10,091.0$ \\
\hline & NamChe 3 & 7.6 & - & 112.6 & - & 3738.0 & - \\
\hline & NamChe 4 & 5.4 & 7.4 & 81.5 & 251.2 & 4710.0 & $13,758.0$ \\
\hline & NamChe 5 & 6.8 & 7.6 & 100.8 & 231.2 & 3139.0 & $12,100.0$ \\
\hline & NERICA 10 & 4.4 & 3.2 & 65.6 & 84.4 & - & 6984.0 \\
\hline & NERICA 6 & 9.7 & 11.5 & 146.9 & 464.9 & 1735.0 & 8618.0 \\
\hline & SUPERICA 1 & 21.5 & 14.7 & 348.7 & 565.2 & - & $10,053.0$ \\
\hline Average & & 10.9 & 10.3 & 159.8 & 373.4 & 4150.5 & $10,588.4$ \\
\hline \multirow[t]{8}{*}{ No Fertilizer } & E22 & 5.6 & 3.9 & 62.9 & 122.4 & 5894.0 & 6851.0 \\
\hline & Local variety & 12.5 & 9.3 & 151.7 & 531.4 & 4019.0 & 6100.0 \\
\hline & NamChe 3 & 6.0 & - & 65.6 & - & 5441.0 & - \\
\hline & NamChe 4 & 6.0 & 4.0 & 70.7 & 129.1 & 6188.0 & 7335.0 \\
\hline & NamChe 5 & 5.6 & 4.8 & 73.6 & 140.0 & 6638.0 & 6732.0 \\
\hline & NERICA 10 & 4.0 & 2.2 & 63.8 & 80.1 & - & 6359.0 \\
\hline & NERICA 6 & 5.7 & 5.6 & 80.2 & 256.3 & 3057.0 & 6260.0 \\
\hline & SUPERICA 1 & 8.8 & 6.4 & 138.1 & 318.2 & - & 6897.0 \\
\hline Average & & 6.8 & 5.2 & 88.3 & 225.4 & 5206.2 & 6647.7 \\
\hline $\operatorname{LSD}_{(\mathrm{P} \leq 0.05)}$ & & 4.5 & 2.9 & 66.0 & 133.2 & NS & 2343.0 \\
\hline $\mathrm{CV} \%$ & & 98.6 & 89.0 & 102.2 & 109.3 & 73.2 & 61.5 \\
\hline
\end{tabular}

${ }^{\star}$ Final disease severity, ${ }^{* *}$ Area under disease progress curve. 

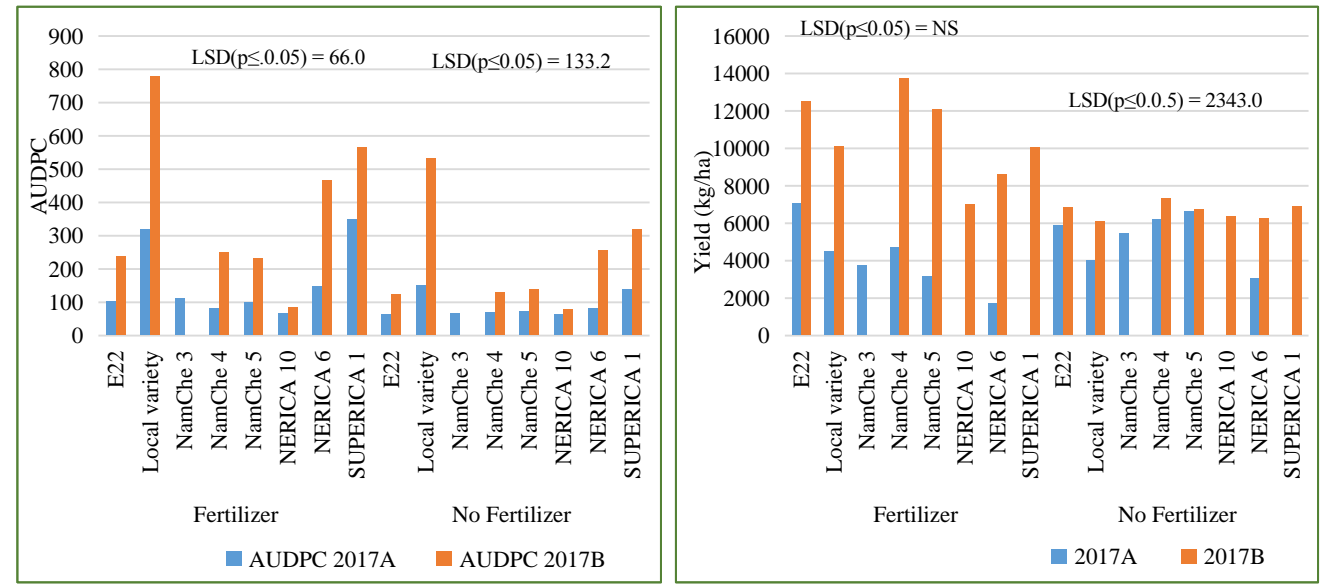

Figure 5. Effect of the fertilizer application $\mathrm{x}$ variety on area under disease progress curve (AUDPC) of leaf blast and yield performance of improved and local upland rice in the South Western Agro Ecological Zone of Uganda.

Varieties that had higher plant vigour and tiller number also had higher yields, which was indicated by the positive correlation $(r=0.168)$ between plant vigour and tiller number. Overall, fertilizer application increased the yields of most varieties by more than double the amounts from the varieties without fertilizers especially for the highest performers such as NamChe 4, E22 and NamChe 5 (Figure 5), which also displayed high rice blast disease resistance and drought tolerance. Although NERICA 10 was the earliest maturing variety, its yield performance was low and not significantly different across the different soil treatments.

The late maturity period of NERICA 6 negatively impacted on its yield performance during the two seasons, but the least performance occurred in the 2017A short season. Therefore, the NERICA varieties displayed lower yield performance than the local famers' mixed varieties and SUPERICA 1, which experienced high blast disease severity during 2017A and 2017B.

Drought characterized by insufficient soil water availability to rice plants, low soil fertility and blast disease were the three major factors that affected upland rice agronomic performance in the Rubirizi and Mitooma districts. At a glance the average yield performance in Rubirizi was higher than in Mitooma, and fertilizer use significantly increased the yields by twice as much especially in Mitooma (Figure 6). The rice performance in Rubirizi sites located at 1005 - 1080 masl was partly attributed to soil types, nutrient status, temperature, humidity and amount of rainfall. The higher yields in Kakali IB, Katabago 2, Kidubule, Nyabishabi and Rwentojo 2 were attributed to soil types with organic matter content of $24 \%-36 \%$, which maintained higher water holding capacity.

Farmer participatory evaluation of plant agronomic characteristics with matrix scores

Although the tillering per hill was low-moderate (1-3) in each site, plots planted using inorganic fertilizers (Table 4) scored slightly higher (2-3) than the 
non-fertilized plots (Table 5). Under the non-fertilized conditions, the local variety consistently showed low tillering at stages 8-9, while SUPERICA 1 and NERICA 6 had low tillering levels in Mitooma only. Apart from NERICA 6, SUPERICA 1 and local Var., which were late maturing, all other varieties displayed early maturity in Rubirizi and Mitooma sites. Interestingly, plots planted using fertilizers displayed early maturing ability than the ones planted without fertilizers. Rice plots planted with fertilizers had bigger panicles at maturity in both sites, but on average Rubirizi had bigger panicles than Mitooma. The levels of grain filling and yielding were higher on plots treated fertilizers in Rubirizi than in Mitooma district. There was no consistent trend in pest tolerance across variety, soil treatment and site, but the level of fungi disease tolerance was higher in the Mitooma sites in than Rubirizi sites. The high disease incidence on NERICA 6, Local var., and NamChe 5 planted with fertilizers in Rubirizi, indicated existence of a high pathogen inoculum in this region that normally experiences higher rainfall, moisture and humidity. The level of drought tolerance was generally low (1-2) in all sites across most varieties apart from SUPERICA 1 and E22. NERICA 6 consistently had lower panicle size, grain filling, drought tolerance, pest and disease tolerance and yielding potential under all conditions in both sites.

Table 4. Agronomic characteristics matrix scores of seven rice varieties at milk-dough growth stages (8-9 stage) in Rubirizi district in the South Western Agro Ecological Zone of Uganda.

\begin{tabular}{|c|c|c|c|c|c|c|c|c|c|}
\hline Soil treatment & Variety & Tillering & Maturity & $\begin{array}{l}\text { Potential } \\
\text { Yield }\end{array}$ & $\begin{array}{c}\text { Panicle } \\
\text { size }\end{array}$ & $\begin{array}{l}\text { Grain } \\
\text { filling }\end{array}$ & $\begin{array}{l}\text { Drought } \\
\text { tolerance }\end{array}$ & Disease & Pest \\
\hline \multirow[t]{7}{*}{ With fertilizer } & E22 & 3 & 1 & 3 & 3 & 3 & 2 & 1 & 1 \\
\hline & LOCAL Var & 3 & 2 & 3 & 3 & 3 & 2 & 3 & 2 \\
\hline & NAMCHE 4 & 3 & 1 & 3 & 3 & 3 & 2 & 2 & 1 \\
\hline & NAMCHE 5 & 3 & 1 & 3 & 3 & 3 & 2 & 3 & 2 \\
\hline & NERICA 10 & 3 & 1 & 3 & 2 & 3 & 2 & 2 & 1 \\
\hline & NERICA 6 & 3 & 2 & 2 & 2 & 2 & 2 & 4 & 1 \\
\hline & SUPERICA 1 & 3 & 1 & 3 & 3 & 3 & 1 & 2 & 1 \\
\hline \multirow[t]{7}{*}{ No fertilizer } & E22 & 2 & 1 & 2 & 2 & 3 & 2 & 1 & 2 \\
\hline & LOCAL Var & 1 & 2 & 2 & 2 & 2 & 2 & 2 & 2 \\
\hline & NAMCHE 4 & 3 & 1 & 3 & 3 & 3 & 2 & 2 & 1 \\
\hline & NAMCHE 5 & 1 & 1 & 2 & 2 & 3 & 2 & 1 & 2 \\
\hline & NERICA 10 & 2 & 1 & 2 & 2 & 3 & 2 & 2 & 1 \\
\hline & NERICA 6 & 2 & 2 & 2 & 2 & 2 & 1 & 2 & 2 \\
\hline & SUPERICA 1 & 2 & 1 & 2 & 2 & 3 & 3 & 1 & 1 \\
\hline
\end{tabular}

Scores: Plant vigour, tillering, yield, panicle size, grain filling, disease severity, pest incidence ( $1=$ low, $5=$ high); maturity period (Early - 1, Late - 2$)$; tolerance to drought $(1=$ low, 3 = High). 
Table 5. Agronomic characteristics matrix scores of seven rice varieties at milk-dough growth stages (8-9 stage) in Mitooma district in the South Western Agro Ecological Zone of Uganda.

\begin{tabular}{|c|c|c|c|c|c|c|c|c|c|}
\hline Soil treatment & Variety & Tillering & Maturity & $\begin{array}{l}\text { Potential } \\
\text { Yield }\end{array}$ & $\begin{array}{l}\text { Panicle } \\
\text { size }\end{array}$ & $\begin{array}{l}\text { Grain } \\
\text { filling }\end{array}$ & $\begin{array}{l}\text { Drought } \\
\text { tolerance }\end{array}$ & $\begin{array}{l}\text { Disease } \\
\text { severity }\end{array}$ & $\begin{array}{c}\text { Pest } \\
\text { incidence }\end{array}$ \\
\hline \multirow[t]{7}{*}{ With fertilizer } & E22 & 3 & 1 & 2 & 2 & 3 & 3 & 1 & 2 \\
\hline & LOCAL Var & 2 & 1 & 3 & 2 & 3 & 2 & 1 & 2 \\
\hline & NAMCHE 4 & 3 & 1 & 3 & 3 & 3 & 2 & 1 & 2 \\
\hline & NAMCHE 5 & 2 & 1 & 2 & 2 & 2 & 2 & 1 & 2 \\
\hline & NERICA 10 & 3 & 1 & 2 & 2 & 2 & 1 & 1 & 1 \\
\hline & NERICA 6 & 2 & 2 & 2 & 2 & 2 & 1 & 1 & 2 \\
\hline & SUPERICA 1 & 2 & 1 & 3 & 2 & 3 & 3 & 2 & 2 \\
\hline \multirow[t]{7}{*}{ No fertilizer } & E22 & 2 & 2 & 3 & 2 & 3 & 1 & 1 & 3 \\
\hline & LOCAL Var & 1 & 1 & 2 & 1 & 2 & 1 & 1 & 3 \\
\hline & NAMCHE 4 & 2 & 2 & 2 & 3 & 3 & 2 & 1 & 3 \\
\hline & NAMCHE 5 & 2 & 1 & 3 & 3 & 3 & 1 & 1 & 3 \\
\hline & NERICA 10 & 2 & 1 & 2 & 2 & 2 & 1 & 1 & 3 \\
\hline & NERICA 6 & 1 & 2 & 2 & 2 & 2 & 1 & 1 & 2 \\
\hline & SUPERICA 1 & 1 & 2 & 2 & 2 & 2 & 2 & 1 & 3 \\
\hline
\end{tabular}

Scores: Plant vigour, tillering, yield, panicle size, grain filling, disease severity, pest incidence $(1=$ low, $5=$ high); maturity period (Early - 1 , Late - 2$)$; tolerance to drought $(1=$ low, $3=$ High $)$.

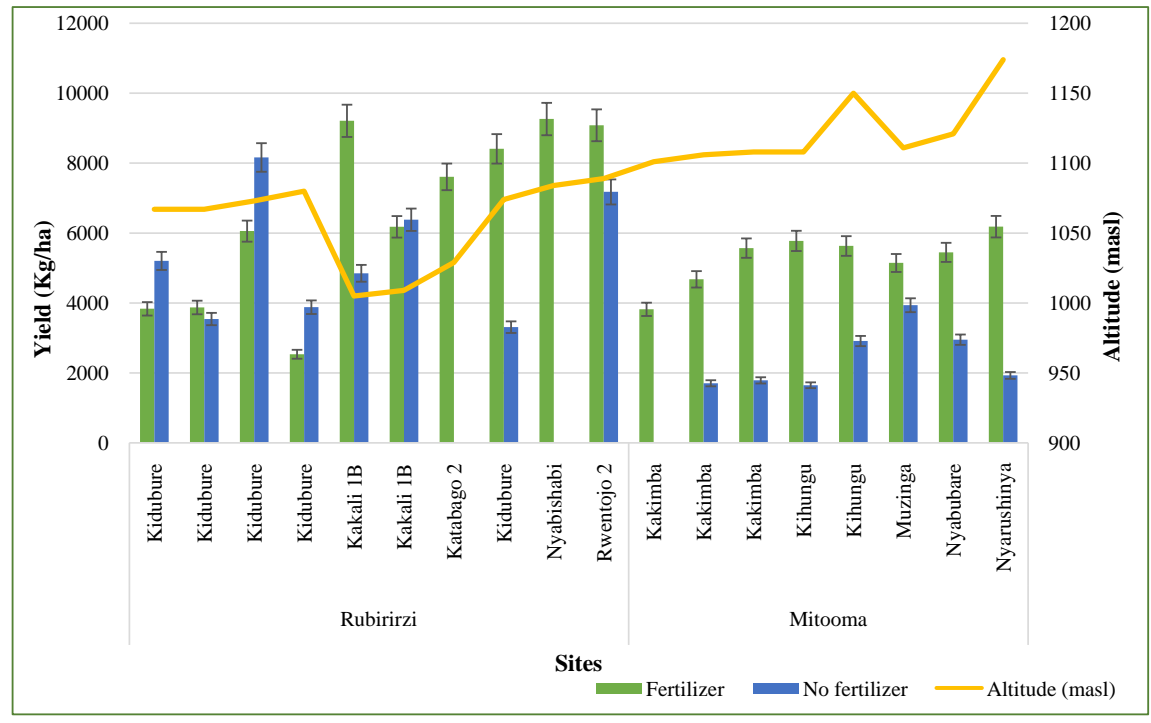

Figure 6. A comparative analysis of upland rice yields from fertilizer and non-fertilizer treated plots across sites in Rubirizi and Mitooma districts in the South Western Ago Ecological Zone of Uganda.

Farmers' preference ranking of improved versus local upland rice varieties

The overall preference ranking of upland rice based on maturity period, dis- 
ease severity, plant vigour, number of tillers per hill, panicle size, grain filling and yielding potential showed that the most preferred variety was NamChe 4 followed by E22 and NamChe 5 (Table 6). Although NERICA 10 was the earliest maturing, its small panicles, low number of tillers and vulnerability to severe bird damage caused to be ranked $4^{\text {th }}$ yet given the climate conditions, NERICA 10 would be the most appropriate upland variety to be grown under prevailing low rainfall conditions. The low performance of NERICA 6 was attributed to unfavourable environmental factors of which low rainfall/moisture and severe drought were major. Therefore, low drought tolerance, lodging, susceptible to bird damage and late maturity were the major limiting characteristics of NERICA 6, SUPERICA 1 and the local var., which had the lowest ranks.

\section{Preference ranking based on graphic comparison}

Comparison of acceptance of rice varieties based on preference assessments showed that NamChe 4 and E22 had higher probabilities being ranked by farmers in the $1^{\text {st }}$ and $2^{\text {nd }}$ positions (Figure 7) under fertilizer treatment, while NamChe 4, NamChe 5 and E22 ranked $1^{\text {st }}, 2^{\text {nd }}$ and $3^{\text {rd }}$ under no-fertilizer application (Figure 8). The three varieties scored high percent probabilities of acceptance under fertilizer and non-fertilizer treatments, thus taking the best four out of the seven ranks (Figure 7 and Figure 8). SUPERICA 1 showed intermediate probability of acceptance under fertilizer and non-fertilizer treatments. Although NERICA 10 had zero probability of ranking $1^{\text {st }}$ under fertilizer treatments (Figure 7), it gained intermediate probability of acceptance from the $2^{\text {nd }}$ rank onwards. NERICA 6, NERICA 10 and Local var., had the lowest probability of acceptance under no fertilizer application (Figure 8).

Table 6. Farmers' preference ranking of different upland rice varieties based on agronomic characteristics in the South Western Agro Ecological Zone of Uganda.

\begin{tabular}{llll}
\hline Rank & Rice variety & $\begin{array}{l}\text { *Percent of } \\
\text { farmers' scores }\end{array}$ & Reasons for ranking \\
\hline 1 & NAMCHE 4 & 75.0 & $\begin{array}{l}\text { Moderate maturity, low blast disease infection, big panicle size, high tillering, high vigour, } \\
\text { high drought and excessive rain tolerant, very high yielding and good grain filling. }\end{array}$ \\
2 & E22 & 70.8 & $\begin{array}{l}\text { Low blast disease, good grain filling, moderate maturity, high vigour, low plant height, } \\
\text { high tillering, high yielding, good panicle, high drought and excessive rain tolerant. }\end{array}$ \\
3 & NAMCHE 5 & 62.5 & $\begin{array}{l}\text { Moderately diseased, low tillering, moderate grain filling, drought tolerant, large panicle } \\
\text { and moderately high yielding. }\end{array}$ \\
4 & NERICA 10 & 59.8 & $\begin{array}{l}\text { Non uniform grain filling, low tillering, very early maturing, big panicle size with large } \\
\text { grains and heavily destroyed by birds. }\end{array}$ \\
5 & Local Var & 56.7 & $\begin{array}{l}\text { Heavily affected by blast disease, susceptible to heavy rains and high logging, low tillering } \\
\text { and small size panicle. }\end{array}$ \\
& SUPERICA 1 & 46.7 & $\begin{array}{l}\text { High tillering, well filled grain, small panicle, high vigour, tall and easy logging, } \\
\text { susceptible to pests (stalk borers) and blast disease. }\end{array}$ \\
7 & NERICA 6 & 40.0 & $\begin{array}{l}\text { Very late maturity, low tillering, highly susceptible to drought, big panicles, high } \\
\text { vegetative growth, resistant to blast and highly vigorous. }\end{array}$
\end{tabular}

*Overall farmers' average percent scores based on personal preference ranking of upland rice varieties. 


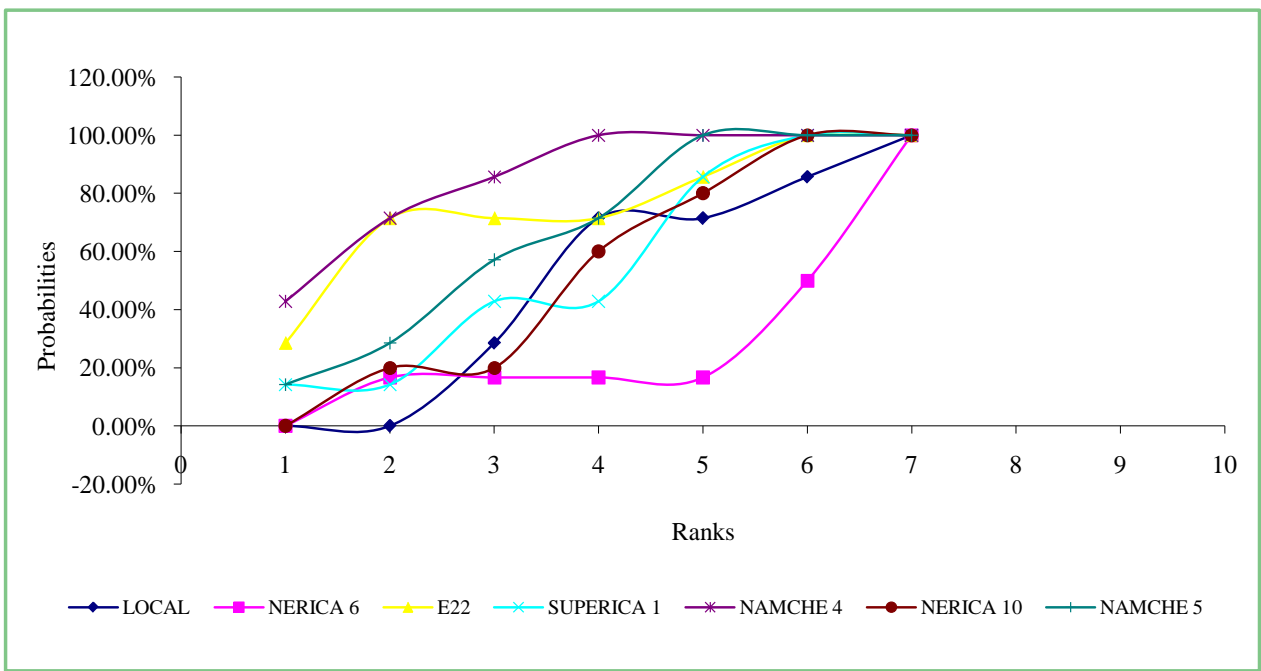

Figure 7. Graphic comparison of acceptance of upland rice varieties under fertilizer application in South Western Agro Ecological Zone of Uganda.

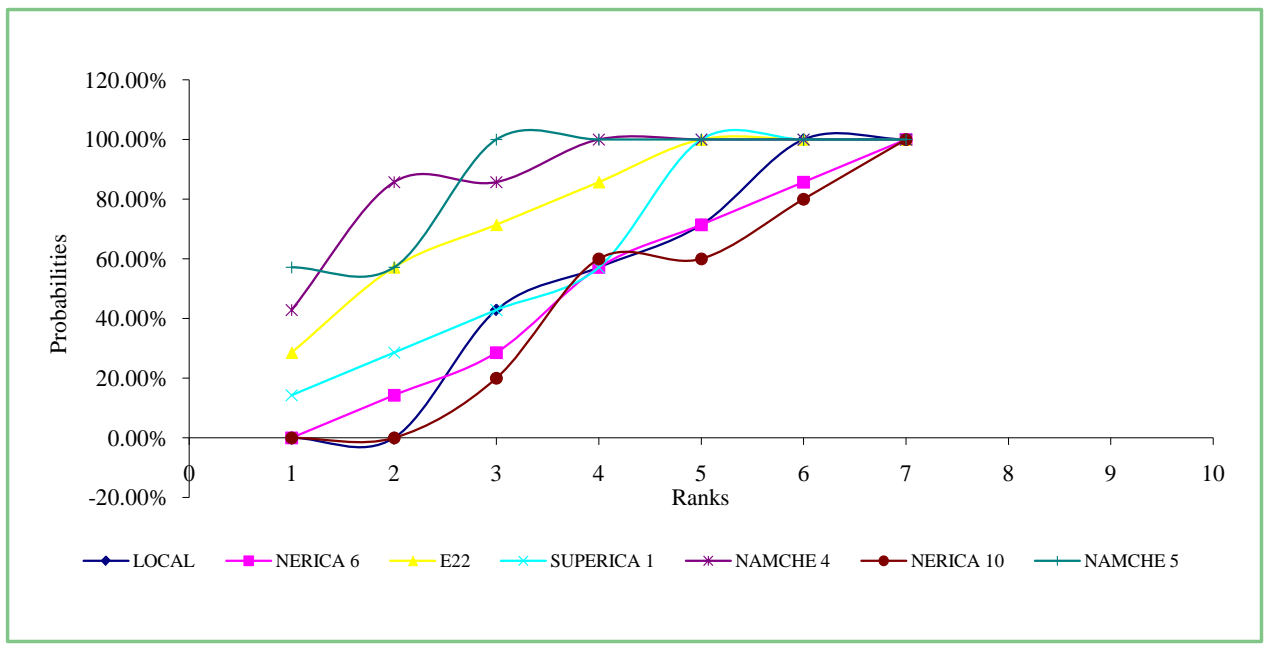

Figure 8. Graphic comparison of acceptance of rice varieties without fertilizer application in South Western Agro Ecological Zone of Uganda.

The statistical analysis of cumulative probabilities versus ranking showed that the NAMCHE 4, E22 and NamChe 5 with slopes (m) of 0.086734694, 0.102040816 and 0.158163265 , positive b-intercepts, low standard deviations (SE) and high correlation coefficients $(73.7 \%, 81.9 \%$ and $91.7 \%)$, respectively, (Table 7) had higher degrees of acceptance in the first positions of ranking at a level of significance of $15 \%$ ( $\mathrm{P} \leq 0.15)$ under fertilizer treatments. Similarly, under no-fertilizer treatments, the three varieties had significantly high degrees of acceptance (Table 8). Although NERICA 6, SUPERICA 1, NERICA 10 and Local Var., had high slopes (m), low standard deviations (SE) and high $\mathrm{r}^{2}$, the negative intercepts $b$ (Table 7 and Table 8) indicates rejection of these varieties with or without fertilizers as regards the first ranking position, and the probability of acceptance in the last ranking position. 
Table 7. Statistical analysis of the differences among the upland rice varieties under fertilizer application based logistic regression.

\begin{tabular}{|c|c|c|c|c|c|c|c|c|c|}
\hline $\begin{array}{l}\text { Rice } \\
\text { variety }\end{array}$ & $\begin{array}{l}{ }^{*} \text { Estimated } \\
\text { parameter }\end{array}$ & $\begin{array}{l}\text { Standard } \\
\text { error }\end{array}$ & $\begin{array}{l}\text { *Estimated } \\
\text { parameter }\end{array}$ & $\begin{array}{l}{ }^{*} \text { Standard } \\
\text { error }\end{array}$ & $\begin{array}{l}\text { Correlation } \\
\text { coefficient }\end{array}$ & Wald & Chi & $\begin{array}{l}\text { The significance } \\
\text { differences }\end{array}$ & the statistical \\
\hline & b (intercept) & (SEb) & m (slope) & (SE) & $\mathbf{r}^{2}$ & Chi-Square & Square & based on a level o & $15 \%$ \\
\hline LOCAL & -0.224489796 & 0.099979173 & 0.183673469 & 0.022356 & 0.931 & 2.245365598 & 0.134015231 & Negative intercept & ${ }^{* *}$ Differ statistically \\
\hline NERICA 6 & -0.214285714 & 0.173335950 & 0.130952381 & 0.038759 & 0.695 & 1.236245076 & 0.266195948 & Negative intercept & Does not differ \\
\hline E22 & 0.346938776 & 0.095722771 & 0.102040816 & 0.021404 & 0.819 & 3.624412178 & 0.056937683 & Positive intercept & ${ }^{* *}$ Differ statistically \\
\hline SUPERICA 1 & -0.102040816 & 0.095177337 & 0.168367347 & 0.021282 & 0.926 & 1.072112535 & 0.300468761 & Negative intercept & Does not differ \\
\hline NAMCHE 4 & 0.510204082 & 0.103560118 & 0.086734694 & 0.023157 & 0.737 & 4.926646391 & 0.026445592 & Positive intercept & ${ }^{* *}$ Differ statistically \\
\hline NERICA 10 & -0.20000000 & 0.085714286 & 0.185714286 & 0.019166 & 0.949 & 2.333333333 & 0.126630458 & Negative intercept & ${ }^{* *}$ Differ statistically \\
\hline NAMCHE 5 & 0.040816327 & 0.095177337 & 0.158163265 & 0.021282 & 0.917 & 0.428845014 & 0.512556227 & Positive intercept & Does not differ \\
\hline
\end{tabular}

Table 8. Statistical analysis of the differences among the upland rice varieties without fertilizer application based logistic regression.

\begin{tabular}{|c|c|c|c|c|c|c|c|c|}
\hline $\begin{array}{l}\text { Rice } \\
\text { variety }\end{array}$ & $\begin{array}{l}\text { Estimated } \\
\text { parameter }\end{array}$ & $\begin{array}{l}\text { Standard } \\
\text { error }\end{array}$ & $\begin{array}{l}{ }^{*} \text { Estimated } \\
\text { parameter }\end{array}$ & $\begin{array}{l}\text { *Standard } \\
\text { error }\end{array}$ & $\begin{array}{l}\text { Correlation } \\
\text { coefficient }\end{array}$ & Wald & Chi & $\begin{array}{l}\text { The significance of the statistical } \\
\text { differences }\end{array}$ \\
\hline & $\mathrm{b}$ (intercept) & $(\mathrm{SEb})$ & m (slope) & (SE) & $\mathbf{r}^{2}$ & Chi-Square & Square & based on a level of $15 \%$ \\
\hline LOCAL & -0.224489796 & 0.08598112 & 0.18877551 & 0.019225963 & 0.951 & 2.610919648 & 0.106130199 & Negative intercept ${ }^{*}$ Differ statistically \\
\hline NERICA 6 & -0.183673469 & 0.035347976 & 0.173469388 & 0.007904048 & 0.990 & 5.196152423 & 0.022636941 & Negative intercept ${ }^{* *}$ Differ statistically \\
\hline E22 & 0.306122449 & 0.090695861 & 0.117346939 & 0.020280211 & 0.870 & 3.375263703 & 0.066181988 & Positive intercept ${ }^{* *}$ Differ statistically \\
\hline SUPERICA 1 & -0.020408163 & 0.095722771 & 0.163265306 & 0.021404262 & 0.920 & 0.213200716 & 0.644270199 & Negative intercept Does not differ \\
\hline NAMCHE 4 & 0.571428571 & 0.118560715 & 0.076530612 & 0.026510982 & 0.625 & 4.819712609 & 0.028136036 & Positive intercept ${ }^{* *}$ Differ statistically \\
\hline NERICA 10 & -0.257142857 & 0.079539491 & 0.178571429 & 0.017785571 & 0.953 & 3.232895436 & 0.072172978 & Negative intercept ${ }^{* *}$ Differ statistically \\
\hline NAMCHE 5 & 0.571428571 & 0.118560715 & 0.076530612 & 0.026510982 & 0.625 & 4.819712609 & 0.028136036 & Positive intercept ${ }^{* *}$ Differ statistically \\
\hline
\end{tabular}

\section{Discussion}

Increasing production of upland rice in Africa is one of strategies to adapt rice cultivation to climate change, which is characterized by longer drought periods, shorter rainfall, warmer temperatures and insufficient water available for agricultural productivity. Of the three major rice production systems (rainfed upland rice, rainfed lowland rice and wetland/lowland irrigated rice) in Uganda, the wetland/lowland irrigation system has been the most productive, giving average yield of $1.9 \mathrm{mt} / \mathrm{ha}$ under high agro-input utilization and intensive management. The current decline in the lowland rice yield in Uganda, which is partly attributed to prolonged drought, insufficient water availability and low soil fertility, is a threat to food security and income especially in regions that are highly dependent on this commodity. Effort to develop high yielding varieties that are adaptable to the diverse environments and tolerant to drought are on-going in Africa [17], and specifically in Uganda where many improved upland rice varieties have been recently released [12]. The current upland rice average yield of milled rice in Uganda is $1.7 \mathrm{t} / \mathrm{ha}$, but it is projected to rise to $2.9 \mathrm{t} / \mathrm{ha}$ with increased use of improved technologies [18]. 
Because in the SWAEZ, rainfed upland rice is grown under minimal agro-input and agronomic management, the yield is commonly very low, a scenario that farmers ignorantly accept as normal. This study assessed the adaptability through agronomic performance and preference evaluation of improved upland rice varieties with fertilizer application on-farm for two cropping seasons in major production districts in the SWAEZ. The assessed agronomic characteristics including plant vigour, height, tillering, disease severity and yield (un-milled), showed significant responses to the fertilizer, variety and fertilizer-variety interaction in the Rubirizi and Mitooma district sites during the short and long rain seasons of 2017. High performance of both improved and local varieties treated with fertilizers based on plant vigour, height, number of headed tillers and yield, was consistent with previous studies elsewhere that have shown varying responses of rice to different fertilizer levels, with the best being the $\mathrm{Ni}$ trogen rate of $120 \mathrm{~kg} \mathrm{~N} / \mathrm{ha}$ [5] [19]. Seasonal rainfall and soil moisture availability to the plant is considered the most important determinant of whether and when rice is planted in this region. It is upon this factor that farmer usually grow rainfed upland rice during the long rain season in order for the crop to have sufficient water. Although the current study agrees with the recommendation of Momolu et al., (2017), that Nitrogen fertilizer should be applied to boost plant growth and yields, these results further showed better fertilizer responses on the 2017B season's crop, which received sufficient rainfall and soil moisture.

The continuous cultivation of upland rice on the same fields season after season creates conducive environments for the buildup of the rice blast pathogen (Magnaporthe grisea) inoculum that normally survive on seed, other hosts, infected residual and volunteer plants. The disease severely infects local upland rice and other related/wild grass species [20] [21]. Blast epidemics observed in this study, are believed to have developed from the massive inoculum that thrived on previous rice plant residues agreeing with studies of Raveloson et al. (2017), which found out that under field conditions, presence of infected rice residues could initiate an epidemic of blast in upland rice [22]. Initial infection and higher disease severity occurred on the local variety and SUPERICA 1, but apart from NERICA 6, NERICA 10 and the NamChe varieties displayed higher disease resistance. The 2017B season characterized by high relative humidity, rainfall and plant vegetative growth experienced high disease especially on the fertilizer treated plots agreeing with the fact that higher Nitrogen fertilizer application favours rice blast epidemics [6]. These results implies the higher rainfall created conducive environments for the pathogen multiplication and survival, moreover, disease severity was higher on the lower leaves in the high inoculum prone, cool and humid environment that was less exposed to sunshine [23]. The least blast affected crops were the 2017B non-fertilized varieties characterized by lower plant vigour, height and tiller formation. Although the current study realized a low negative blast AUDPC-yield correlation on the upland rice varieties, higher positive correlations $\left(r^{2}=0.95\right)$ between yield loss and disease severity on susceptible irrigated lowland rice have been reported [24]. The high disease se- 
verity observed on the local mixed variety and SUPERICA 1 , may indicate that these varieties are either susceptible to Magnaporthe grisea or the endemic pathogen races are virulent to the existing resistance. However, the existence of conidia in the environment season after season, and the likely presence of the pathogen in seed [25], may have generated the high inoculum that resulted in severe disease epidemics that spread to improved varieties. Rice blast can cause up to $90 \%$ yield loss on susceptible varieties, but germplasm evaluation studies have identified externally introduced genotypes with high to moderate resistance to $M$. grisea races existing in Uganda that can be used to improve the most preferred varieties with durable blast resistance gene pyramids [6]. Besides NamChe 3, which has been previously reported as a potential source of disease resistance [12], NERICA 10 consistently displayed higher resistance to rice blast. A combination of early maturity with high blast resistance qualifies NERICA 10 as a promising climate change and disease resilient variety, but because of its low yielding, it is best utilized as a source of genes to improve other high yielding and consumer/market preferred rice varieties. Given the importance of rice blast worldwide, appropriate control approaches integrating cultural, judicial chemical use and varietal resistance need to be applied for effective management of the disease.

Apart from genotype E22 (yielded 6443 - 10,036 Kg/ha un-milled rice during 2017A and B), NamChe 4 and NamChe 5 released in 2013 displayed higher agronomic performance and tolerance to low soil moisture over NERICA 6 and local varieties (SUPERICA 1 and local Var.). The potential yields of NamChe 4 and NamChe 5 at the time of release were 4500 and $5800 \mathrm{Kg} / \mathrm{ha}$ [12], but in the current study, the average yield range of these varieties were $4889-5449 \mathrm{Kg} / \mathrm{ha}$ and $9416-10,547 \mathrm{Kg} / \mathrm{ha}$ of unmilled rice in 2017A and 2017B, respectively, in the SWAEZ. Combination of improved variety with fertilizer application plus appropriate agronomic management resulted in higher upland rice performance in the zone, whereby in some sites yield increased by $\geq 100 \%$. Therefore, improved varieties have a great potential of increasing rice production in SWAEZ, if farmers adopt improved varieties together with agro-input use [14] [18], and proper rice production techniques [15] [26]. Considering the high rate at which NERICA has been adopted in Central Uganda, which was partly because of its high yields, there is a very high probability of farmers adopting the tested improved upland rice varieties for increasing production and consequently income.

Farmer participatory evaluation of technologies is an essential stage in technology development, because it is a key determinant of whether the technology is appropriate for adoption by the target users/consumers or unacceptable [27]. A combination of matrix scores using a modified scale and preference ranking logistic regressions showed that improved rice varieties; NamChe 4, NamChe 5 and E22 had significantly high probability of acceptance because these varieties had the qualitative and quantitative attributes required by farmers under their production and marketing conditions. The key attributes that influenced upland rice variety acceptance in the current study included; drought tolerance, early maturity period, yield, panicle size and grain filling, but elsewhere, studies have 
shown that consumer preferred improved rice varieties developed based on information derived through participatory variety selection may increase production, utilization and marketability [28]. Although local upland rice varieties were agronomically low performing and ranked least in the current study, farmers continue to grow them mainly because of high drought tolerance and early maturity period.

\section{Conclusion}

In conclusion, the high agronomic performance of some of improved upland rice varieties in the SWAEZ indicated a great potential of rice production in the region. However, besides the unpredictable drought spells; proper management of soil fertility, moisture, pests and diseases can result in higher rice yield performance than expected. The improved variety-fertilizer combination plus appropriate agronomic management resulted in higher rice agronomic performance in the two experimental sites. Improved NamChe 4, NamChe 5 and E22 not only showed superior agronomic performance over the other varieties in the field, but scored the highest probability of being accepted by farmers. The early maturing NERICA 10, late maturing NERICA 6, SUPERICA 1 and Local Var., had probabilities of being rejected because of low yielding, late maturity, high drought intolerance, high susceptibility to rice blast caused by Magnaporthe grisea, small panicle size and poor grain filling abilities. Therefore, improved varieties have a great potential of increasing rice production in SWAEZ, if farmers adopt improved varieties together with agro-input use and proper rice production techniques. Considering the high rate at which NERICA has been adopted in Central Uganda, which was partly because of its high yields, there is a very high probability of farmers adopting the tested improved upland rice varieties for increasing production and consequently income.

\section{Acknowledgements}

The authors greatly thank Dr. Jimmy Lamo for kindly providing early generation seed of the improved upland rice varieties used in this study. Special thanks to the farmers that hosted the experiments in Mitooma and Rubirizi districts, Uganda. We thank the technician and intern students for their support in establishing, monitoring and managing of the on-farm experiments.

\section{Funding}

This study was funded by the World Bank in collaboration with Government of Uganda through the National Agricultural Research Organization (NARO) Uganda under the Agricultural Technology and Agribusiness Advisory Services (ATAAS) Project.

\section{Conflicts of Interest}

The authors declare no conflicts of interest regarding the publication of this paper. 


\section{References}

[1] Demont, M. (2013) Reversing Urban Bias in African Rice Markets: A Review of 19 National Rice Development Strategies. Global Food Security, 2, 172-181.

https://doi.org/10.1016/j.gfs.2013.07.001

[2] Ministry of Agriculture, Animal Industry and Fisheries (MAAIF) (2018) Uganda National Rice Development Strategy 2008-2018. Rice Self-Sufficiency in Uganda by 2018. 73.

[3] Kikuchi, M., Kijima, Y., Haneishi, Y. and Tsuboi, T. (2014) A Brief Appraisal of Rice Production Statistics in Uganda. Tropical Agriculture and Development, 58, 78-84.

[4] Oonyu, J. (2011) Upland Rice Growing: A Potential Solution to Declining Crop Yields and the Degradation of the Doho Wetlands, Butaleja District-Uganda. African Journal of Agricultural Research, 6, 2774-2783.

[5] Momolu, E.P., Lamo, J. and Katuromunda, S. (2017) Soil Moisture Stress and Nitrogen Supply Affect the Growth Characteristics and Yield of Upland Rice Cultivars.

[6] Zewdu, Z., Gibson, P., Lamo, J. and Edema, R. (2017) Reaction of Introduced Korean Rice Genotypes for Resistance to Rice Blast in Uganda. Journal of Plant Breeding and Crop Science, 9, 98-105. https://doi.org/10.5897/JPBCS2017.0641

[7] Tsujimoto, Y., Rakotoson, T., Tanaka, A. and Saito, K. (2019) Challenges and Opportunities for Improving N Use Efficiency for Rice Production in Sub-Saharan Africa. Plant Production Science. https://doi.org/10.1080/1343943X.2019.1617638

[8] Ali, M.A., Inubushi, K., Kim, P.J. and Amin, S. (2019) Management of Paddy Soil towards Low Greenhouse Gas Emissions and Sustainable Rice Production in the Changing Climatic Conditions. In: Soil Contamination and Alternatives for Sustainable Development, IntechOpen, London, Vol. 6, 90-107.

[9] Anastasi, C., Dowding, M. and Simpson, V. (1992) Future CH4 Emissions from Rice Production. Journal of Geophysical Research: Atmospheres, 97, 7521-7525. https://doi.org/10.1029/92JD00157

[10] Kijima, Y., Sserunkuuma, D. and Otsuka, K. (2006) How Revolutionary Is the "NERICA Revolution"? Evidence from Uganda. The Developing Economies, 44, 252-267. https://doi.org/10.1111/j.1746-1049.2006.00016.x

[11] Haneishi, Y. (2014) Rice in Uganda: Production Structure and Contribution to Household Income Generation and Stability. Thesis, Graduate School of Horticulture Chiba University, Matsudo City, Japan, 120.

[12] Lamo, J., Tongoona, P., Sie, M., Semon, M., Onaga, G. and Okori, P. (2017) Upland Rice Breeding in Uganda: Initiatives and Progress. In: Advances in International Rice Research, IntechOpen, London, 11, 215-246. https://doi.org/10.5772/66826

[13] Haneishi, Y., Maruyama, A., Asea, G., Okello, S.E., Takagaki, M. and Kikuchi, M. (2013) Exploration of Rainfed Rice Farming in Uganda Based on a Nationwide Survey: Regionality, Varieties and Yield. African Journal of Agricultural Research, 8, 4038-4048.

[14] Kaizzi, K.C., Nansamba, A., Kabanyoro, R., Lammo, J. and Rware, H. (2018) Upland Rice Response to Fertilizer in Three Agro-Ecological Zones of Uganda. African Journal of Plant Science, 12, 65-72.

[15] Kijima, Y. (2018) Long-Term and Spillover Effects of Rice Production Training in Uganda. 
[16] Van Oort, P.A. and Zwart, S.J. (2018) Impacts of Climate Change on Rice Production in Africa and Causes of Simulated Yield Changes. Global Change Biology, 24, 1029-1045. https://doi.org/10.1111/gcb.13967

[17] Saito, K., Asai, H., Zhao, D., Laborte, A.G. and Grenier, C. (2018) Progress in Varietal Improvement for Increasing Upland Rice Productivity in the Tropics. Plant Production Science, 21, 145-158. https://doi.org/10.1080/1343943X.2018.1459751

[18] Nhamo, N., Rodenburg, J., Zenna, N., Makombe, G. and Luzi-Kihupi, A. (2014) Narrowing the Rice Yield Gap in East and Southern Africa: Using and Adapting Existing Technologies. Agricultural Systems, 131, 45-55. https://doi.org/10.1016/j.agsy.2014.08.003

[19] Kaizzi, K., Byalebeka, J., Semalulu, O., Alou, I., Zimwanguyizza, W., Nansamba, A., Odama, E. and Wortmann, C. (2014) Upland Rice Response to Nutrient Application in Uganda. African Journal of Plant Science, 8, 416-425.

[20] Dean, R.A., Talbot, N.J., Ebbole, D.J., Farman, M.L., Mitchell, T.K., Orbach, M.J., Thon, M., Kulkarni, R., Xu, J.-R. and Pan, H. (2005) The Genome Sequence of the Rice Blast Fungus Magnaporthe grisea. Nature, 434, 980.

https://doi.org/10.1038/nature03449

[21] Gladieux, P., Condon, B., Ravel, S., Soanes, D., Maciel, J.L.N., Nhani, A., Chen, L., Terauchi, R., Lebrun, M.-H. and Tharreau, D. (2018) Gene Flow between Divergent Cereal- and Grass-Specific Lineages of the Rice Blast Fungus Magnaporthe oryzae. Mbio, 9, e01219-e01217. https://doi.org/10.1128/mBio.01219-17

[22] Ravelosona, H., Ramontab, I.R., Tharreauc, D. and Sesterd, M. (2017) Long-Term Survival of Blast Pathogen in Infected Rice Residues as Major Source of Primary Inoculum in High Altitude Upland Ecology. Plant Pathology, 67, 610-618. https://doi.org/10.1111/ppa.12790

[23] Greer, C. and Webster, R. (2001) Occurrence, Distribution, Epidemiology, Cultivar Reaction and Management of Rice Blast Disease in California. Plant Disease, 85, 1096-1102.

[24] Bonman, J., Estrada, B., Kim, C., Ra, D. and Lee, E. (1991) Assessment of Blast Disease and Yield Loss in Susceptible and Partially Resistant Rice Cultivars in Two Irrigated Lowland Environments. Plant Disease, 75, 462-466.

https://doi.org/10.1094/PD-75-0462

[25] Faivre-Rampant, O., Genies, L., Piffanelli, P. and D, T. (2013) Transmission of Rice Blast from Seeds to Adult Plants in a Non-Systemic Way. Plant Pathology, 62, 879-887. https://doi.org/10.1111/ppa.12003

[26] Kijima, Y., Ito, Y. and Otsuka, K. (2012) Assessing the Impact of Training on Lowland Rice Productivity in an African Setting: Evidence from Uganda. World Development, 40, 1610-1618. https://doi.org/10.1016/j.worlddev.2012.04.008

[27] Bhargava, A. and Srivastava, S. (2019) Advantages and Cost of Participatory Plant Breeding. In: Participatory Plant Breeding. Concept and Applications, Springer, Berlin, 87-107. https://doi.org/10.1007/978-981-13-7119-6 4

[28] Mogga, M., Sibiya, J., Shimelis, H., Lamo, J. and Ochanda, N. (2019) Appraisal of Major Determinants of Rice Production and Farmers' Choice of Rice Ideotypes in South Sudan: Implications for Breeding and Policy Interventions. Experimental Agriculture, 55, 143-156. https://doi.org/10.1017/S0014479718000017

[29] Shaner, G. and Finney, R. (1977) The Effect of Nitrogen Fertilization on the Expression of Slow-Mildewing in Knox Wheat. Phytopathology, 67, 1051-1056. https://doi.org/10.1094/Phyto-67-1051 
[30] Mukherjee, A.K., Mohapatra, N.K. and Nayak, P. (2009) Estimation of Area under the Disease Progress Curves in a Rice-Blast Pathosystem from Two Data Points. European Journal of Plant Pathology, 127, 33-39.

https://doi.org/10.1007/s10658-009-9568-2 